\title{
o sujeito encena ou sujeito a risco
}

CARLOS EDUARDO SCHMIDT CAPELA Universidade Federal de Santa Catarina - CNPq, Brasil / capela@cce.ufsc.br

\section{Resumo}

Desdobramentos do episódio do encontro entre Odisseu e Nausícaa, narrados a partir do Canto VI da Odisseia, quando o herói finalmente alcança a ilha dos Feácios, são no ensaio discutidos sobretudo com base na ocorrência do choro. O pranto desarma o ímpeto belicoso e facilita a integração daqueles que a ele se entregam aos grupos de que fazem parte, ou que os asilam. Num segundo momento, a recriação do mesmo episódio, no Ulysses, de James Joyce, é enfocado, sendo então realçados os inevitáveis contrastes daí advindos, resumidos na troca do lamento solidário acentuado por Homero pela busca egoística, ou romântica, de prazer e sucesso.

Palavras chave: Odisseia / Ulysses / pranto/intolerância /voyeurismo

\section{the subject on the scene or subject to risk}

Abstract

Developments in the episode of the encounter between Odysseus and Nausicaa, narrated from the sixth canto of the Odyssey, when the hero finally reaches the island of the Phaeacians, are in the essay discussed mainly based on the occurrence of crying. Weeping disarms the bellicose impetus and facilitates the integration of those who give themselves to the groups of which they are part or host them. In a second moment, the re-creation of the same episode, in James Joyce's Ulysses, is focused, emphasizing the inevitable contrasts, summarized in the exchange of the solidarity lament accentuated by Homer for the egoistic, or romantic, pursuit of pleasure and success.

Key words: Odyssey / Ulysses / crying / intolerance / voyeuurism

Recibido: 20/02/2019. Aceptado: 04/04/2019

Para citar este artículo: Schmidt Capela, Carlos Eduardo (2019). o sujeito encena ou sujeito a risco. El taco en la brea, 9 (diciembre-mayo), 64-76. Santa Fe, Argentina: UNL. DOI: 10.14409/tb.v1ig.8190 


\section{As lágrimas...}

Homessa Homero! Mais uma vez começa contigo a conversa. Ou melhor, começa de fato com a Musa, aquela por tua voz conclamada. E que de imediato, através de ti, após «destruída Troia», airosa «canta», do «homem multiversátil», «as muitas errâncias».' Desde sempre, então.

Por isso, ao contemplar as ruínas de um templo solar já de antemão assolado, é confiando em tua sensata sabedoria que reitero o premente exórdio: — «Filha de Zeus, começa o canto de algum ponto!» (13). Esse ponto, agoraqui, sobrevém da fúria do mar: o Canto VI.

«Odisseu magnânimo», o «herói plurissofrido» (175) na ocasião adormecido sobre o desconhecido solo feácio, é despertado por um feminil «grito estrídulo» (181). Ávido de conhecer o que em torno sucedia, ele «emerge dos arbustos» atrás dos quais se ocultara. «Embora nu», pois não cuidara de «velar a genitália» (181), avança firme «entre as moças belas-tranças» (183) da coorte que acompanhava a "filha do longânime Alcínoo», rei dos feácios, moça de "curvas e expressão divinas» (175). Tal uma Afrodite renascida invertida, um disíacoafro, «desponta sujo de salsugem, horrível» (183), e assim se apresenta diante de uma Nausícaa enfeitiçada pelas artes da astuta Ateneia, que «encorajou sua mente e desapavorou-lhe os membros» (183).

Ao invés de suplicante agarrar-se aos joelhos da donzela o herói opta por alvejá-la com «palavras-mel e maturadas» (183). O vigor da expressão, a par da elegância e do apuro retórico, visam a suprir o desconjunto do vivente que destarte adentra um novo cenário, cujo prodígio ganha o alento do contraste propiciado por sua miserável aparência. Uma das manhas propaladas pela epopeia é aqui ratificada: ele irá magnificar aquela a quem se dirige, projetando sobre ela os valores que se dá, e que o movem. Afirma sentir-se extasiado diante da formosura digna de uma Ártemis cercada por seu séquito de esbeltas ninfas, e, caso fosse ela uma mortal, hiperboliza, «jamais [pudera] ver pessoa (um ou uma) equiparável a quem vejo e rendo loas!» (183).

Só depois é que se aplica a justificar o desvalido estado atual. Oferece para tanto um excerto mínimo do seu mais recente infortúnio: a partida da ilha Ogígia e a luta contra o mar turbilhonante que culminaram em sua condição de estrangeiro, de um hostis à procura do hospes que lhe correspondesse. O mais importante sendo convencê-la, seduzi-la a fim de angariar sua simpatia, deixa na sombra o nome de Calipso, a ninfa que, elegendo-o como «consorte» (151), em sua aprazível gruta intermitente o abrigara, e obrigara, ao longo de sete estendidos anos.

As agruras por que passam exigem dos guerreiros épicos testemunhar sobre si mesmos, quando menos soerguerem-se apoiados no verbo de terceiros, preço que o heroísmo lhes cobra, a bem da glória de todos. Quanto ao escrutínio acerca do grau de verossimilhança dos testemunhos, e de sua coerência, cabe aos leitores realizá-lo, por intermédio de sua também épica lida. Esse é um dos motivos pelos quais o universo epopeico oferecido aos sentidos configura um feérico espetáculo.

Que se apresenta, para tanto, terrível e inelutavelmente cindido, avesso a concretizações simbólicas. Tão só esvai, esvairado, esvaecido, e nos entrementes de tal fluxo entretece relações díspares, modulando-as segundo o diapasão de imponderáveis fantasias. Em seu domínio, de todo modo, o poder, inclusive o poder de ser e a vontade de poder, ao se verem inscritos acabam por se surpreender -ex-critos. ${ }^{2}$ À auto-fundada e auto-fundante força da lei, com seu afã perseverante de dar vazão e razão a heroísmos, resta a opção de derivar em força de lei, isso que vige em meio a corpos. Daí a precisão, ali e alhures, de a ambas colocar fora de si, para, na sequência, trazê-las de volta, ressabiadas porém pela iminência do sucesso de seu próximo fracasso. Resulta um jogo, uma dança com seus contratempos, um postergar sem fim: pas de deux. 
O sofisticado tagarelar de Odisseu amolece a princesa, que aceita acolhê-lo e lhe servir de guia na terra incógnita. A intrepidez dos atos e os arroubos discursivos podem com isso arrefecer, e ceder lugar ao acanhamento. No herói assim irrompe, sem mais tardança, o "pudor de que [o] vejam nu» (187) as donzelas todas. Ele se revela consciente de que há que zelar para que a proteção que lhe vem da outra não afrouxe. Daí a necessidade de ao menos parecer ser como aquela a quem dirige a palavra. Discursos, afinal, aprendeu Polifemo, como as demais roupagens e seus adereços, velam. Isto é, camuflam ou mascaram, de qualquer maneira resguardam.

Não bastasse o apuro do banho, complementado pelo brilho perfumado dos óleos com que, recusado o serviço das fâmulas, ele mesmo untara seu corpo, antes de vestir «a roupa, dádiva da moça» (187), Atena o faz «maior e mais troncudo, seus cabelos encaracolou cabeça abaixo tais e quais jacinto em flor» (187). Então Nausícaa, subjugada pela imponência da magistral beleza grega, enfim proclama: «Minha impressão primeira era a de um ser ignóbil e bruto, agora é como um deus que habita o céu». E alto e bom som professa, ela também ávida de conquista: «Pudera eu ter um ente assim como consorte, que, em sua visita, decidisse não partir» (189).

$\mathrm{O}$ anseio será mais tarde transfigurado em proposta, proveniente de Alcínoo, que oferece a Odisseu a filha em casamento caso ele aceitasse permanecer no país. Como em toda a sua espezinhada trajetória retorno e abandono se imbricam, compensando-se mutuamente, a recusa do enlace é adoçada pela promessa, feita à virgem casadoura, de que preservará vivo, na memória, o elo que os congregou. Uma vez de volta ao lar, diz a ela o herói, «serás por mim, todos os dias, sempre, louvada, pois a vida (...) me salvaste!» (243).

Antes disso, porém, nessa odisseia em miniatura a moça o conduzira às cercanias do palácio do pai, onde, segundo seu conselho, deveria antes de tudo tentar alcançar o beneplácito da mãe. Só então o almejado regresso a Ítaca estaria garantido. Canto VII adentro Odisseu obtém sucesso na empreitada, contando sempre com a explícita ajuda de Palas Atena. Alcínoo, para quem «sopesar tudo é melhor» (213), compromete-se a providenciar-lhe uma naval «escolta a fim de que, sem dor e sem fadiga, alcance a pátria, alegre, presto, num cortejo atento» (205).

O soberano feácio irá manter a palavra, o que assegura ao herói o cumprimento de sua peripécia futura, aquela que em Ítaca o aguarda. Diante disso, passa a caber a ele, o ardiloso, mostrar-se digno das confianças todas nele depositadas. Será posto a provas, as competições olímpicas de que logo depois participa sendo as mais simples delas. Uma primeira é devida à curiosidade de Areste, esposa de Alcínoo, que indaga: «Hóspede, começo demandando tua identidade. De onde vens? Quem te presenteou com essas roupas? Não te dizias náufrago do mar talássio?» (209). Em resposta Odisseu oferece uma versão, mais bem acabada, do episódio versos atrás narrado a Nausícaa. $\mathrm{O}$ acento, agora, é posto sobre o crescente amargor que o perseguiu durante os sete anos de exílio convividos com Calipso.

Se por um lado menciona o pródigo asilo recebido da deusa, que para atraí-lo, atesta, chegara mesmo a propor transformá-lo em «um deus, perene» (209), de outro enfatiza o pouco ardor que por ela nutria. No relato do tenaz naufragante emerge nesse momento a imagem do choro, afecção que o teria acompanhado ao longo de todo aquele período: «Por um setênio ali fiquei, banhando sempre de pranto a vestimenta ambrósia, dom da deusa» (209), essa mesma Calipso que ao final, a pedido de Zeus, irá incentivá-lo a voltar para casa. ${ }^{3}$

Alcínoo na sequência convida os compatriotas a compartilharem a "recepção fraterna ao hóspede» (219), por ele organizada. Findo o repasto, Demódoco, «aedo insigne» a quem a Musa 
concedeu «o bem e o mal: [privando-o] de visão, mas não do canto doce» (221), por ela instigado celebra o episódio do desentendimento entre Aquiles e Odisseu, clara remissão, entre tantas outras, à Ilíada. Ao escutá-lo este não consegue conter as lágrimas, mas tenta escondê-las: «O herói se aferra ao manto púrpura com mãos enérgicas e o traz à testa, encobre a expressão do rosto: 0 pranto defluir dos cílios frente aos feácios o envergonhava» (221). Nenhum dos convidados percebe o choro, salvo Alcínoo. ${ }^{4}$

Seguem os jogos, no quais Odisseu demonstra suas esplêndidas força e destreza. Mais tarde, como de praxe, festejam com um novo banquete, depois do qual Demódoco, agora qualificado como aquele a quem a Musa «ensina as vias de onde o canto aflora» (243), outra vez intervém. Acatando um perspicaz pedido de Alcínoo, o vate desta feita verseja sobre o ardil do cavalo de Troia. Ao entendê-lo, Odisseu «se desfazia em pranto, o rio de lágrimas rolando à face» (247). Isso até que o rei, ainda o único a notar que o «hóspede não mais reteve o pranto» (247), interrompe a cantoria, solicitando ao convidado esclarecer os motivos de seu prantear. Só então, a partir do Canto IX, o herói proclama seu nome e proveniência, e relata à assembléia as proezas realizadas desde que atrás de si deixara Troia arrasada, nessa que é uma das principais odisseias na Odisseia, entre as diversas comentadas por Italo Calvino, e que, dada sua disposição em um mesmo plano, constroem um sofisticado mosaico narrativo. ${ }^{5}$

Similar ao canto, que demoníaco aflora graças aos transportes das graças divinas, o pranto provém daquele lugar incerto que na falta de melhor nome denominamos o interior de cada qual, o interior intimo meo de Agostinho, isso que nos rasga desde dentro e nos lança para fora. Através dele a intimidade do corpo nu, «mais íntima do que o íntimo», ${ }^{6}$ extra-vaza. Mas o canto é desejado e louvado, posto que congregante, enquanto o choro tão somente brota, surpreendente e incontinente, pontual embora contagiante. Não deixa de ser o estrugimento de um estruir, que escapa de uma ob-strução devassada, de um acontecimento que a um só tempo implica contiguidade e desorganização, constituindo um seguro indício da derrocada de quaisquer archés sistemáticas.?

O choro, caso seja neste contexto escusado trazer à baila Walter Benjamin, assim como a mancha, ou o rubor nas maçãs do rosto, «se destaca, de dentro para fora». ${ }^{8}$ Ele atesta um arrebatamento que aflui, funcionando como um «meio» de acesso. Permite àqueles que o veem atravessar o corpo de outrem, ao modo de um sintoma, tomar consciência de algo que, sem ele, poderia ter sido mantido incógnito —o secretar das lágrimas desampara o secreto.

Por conta de seu caráter reativo o choro, ademais, traz consigo uma dimensão temporal. Através dele passado e futuro confluem no presente em que jorram e se espalham. Daí o heroísmo, entendido como força pura e bruta, isso que, em sendo, sempre é quando menos suposto - tal e qual o próprio sujeito que sustém, sobre o qual Jean-Luc Nancy não se cansa de refletir-, ${ }^{9}$ daí o heroísmo frente a ele se recolher, como que para se deixar purgar. Seu efeito é portanto análogo àquele da mancha, que, conforme Benjamin, aporta «uma significação que desintegra a personalidade em certos elementos primitivos» (84), nos quais culpa e expiação se sobrepõem. Ele, com efeito, desfigura, demandando posterior recomposição, que por sua vez pode vir a ser mais tarde desfigurada, todas porém deixando marcas atrás de si, num processo similar àquele que Freud, ao seguir alguns rastros de Moisés, mais um dos célebres egípcios miscigenados, nomeou como «Entstellung».10 Em resumo: informe e inconforme por excelência, o choro informa e conforma.

Enquanto o signo é indicial, apontando para um atributo ou uma caraterística expressa e própria, evidentemente singular, o pranto sugere a existência de laços que, reafirmados através dele, 
reenviam aquele que com ele se esvai, alquebrado, à comunidade da qual fez ou faz parte. Como ele ao mesmo tempo demanda a explicitação de seus motivos, o que só é factível pela mediação de alguma modalidade de linguagem, em sendo o chorão um estranho, tal Odisseu entre os feácios, 0 relato que esclarece as paixões afetadas, caso efetuado, favorece a integração ao grupo hospedeiro.

Tal caráter propedêutico do choro foi realçado por Aristóteles, que o elenca entre as modalidades de reconhecimento que se devem à lembrança, citando como um dos exemplos justamente o lamento do guerreiro "ao ouvir o citarista»." Dada a sua inclinação em valorizar a sequencialidade das ações, o que o leva a sobrestimar os reconhecimentos resultantes dos próprios acontecimentos que o entornam, Aristóteles, no entanto, ao menos nos fragmentos sobreviventes da Arte poética, pouco se alonga sobre situações patéticas, limitando-se a indicar suas causas como decorrentes de «uma ação que provoca a morte ou sofrimento» (283).

Na Odisseia, no entanto, são como visto recorrentes situações em que os protagonistas se debulham em lágrimas. ${ }^{12} \mathrm{O}$ choro ali enodoa, denuncia fraquezas, suspende os ímpetos da coragem. Sem esta, como ocorre com Odisseu quando impressiona Nausícaa, os heróis apercebem-se nus, desencobertos e despundonorosos. Isso ajuda a compreender um dos motivos pelos quais Pisístrato, no episódio da visita de Telêmaco a Menelau, no Canto IV, ao constatar estarem todos tomados por um irreprimido prantear coletivo, interfere imediatamente para solicitar ao anfitrião «de à mesa suspendermos nosso pranto» (105). A que Menelau assente: «Suspendamos o pranto a que nos entregamos! Tornemos ao banquete» (107).

Bem nesse momento o foco épico assume a perspectiva da "divina Helena», exímia conhecedora das almas humanas. Levando em conta o quase insuperável hiato entre a resolução e a sua efetividade ela então

labora um plano diferente: versa fármaco no vinho que bebiam: sofrimento, cólera, os males memoráveis, tudo amortecia. Quem sorvesse a mistura da cratera funda, susteria o lamento na extensão de um dia, mesmo se mortos pai e mãe, mesmo se mortos à sua frente, a fio de bronze, irmão ou filho. (107)

O canto na sequência detalha: «A filha do Cronida recebera o fármaco (...) de Polidama, mulher de Tone, a egípcia. O solo fértil mana bastante droga, que repara ou que assassina. Os médicos mais doutos são do Egito» (107).

Quem chora não se entrega a uma desordem supranormal, proporcionada, por exemplo, por aquele terceiro gênero que Platão denomina khôra, sobre a qual, assinala Jacques Derrida, não se pode «nem mesmo dizer que ela não é nem isto, nem aquilo, ou que é ao mesmo tempo isto e aqui10», ${ }^{13}$ isso para o desespero do equilibrado Erich Auerbach, caso pudesse tê-lo lido? Chorar não é se deixar transportar para um domínio regido por essa khôra assombrosa, cujo pensamento inquieta «a própria ordem da polaridade», dado ela não mais pertencer «ao horizonte do sentido, nem do sentido como sentido do ser» (16)?

Pois a «khôra é anacrônica, ela «é» a anacronia no ser, ou melhor, a anacronia do ser. Ela anacroniza o ser» (18), transformando-o em um isto que não é substancial como um cachimbo, e tampouco «é um sujeito. Não é o sujeito. Nem o substrato» (19), mas quiçá o próprio da impropriedade. De todo modo, à semelhança do que ocorre no Timeu, «tudo está escrito» na Odisseia, ela também constituindo um «lugar que recebe tudo» (53). O choro ali e-mociona, é e-motivo. Ele co-move o cantar, oferecendo-lhe frações de potência que facilitam seu deslocamento em torno dos tantos 
heróis a que dá luz. Há portanto que na epopeia reconhecer, além das estrepolias de Odisseu, todas as várias outras odisseias disseminadas em torno e a partir dele, os encantados relatos que $o$ bordejam e nos encantam.

É o que traduz Derrida:

Cada narrativa é, então, o receptáculo de uma outra. Somente há receptáculos de receptáculos narrativos. Não esqueçamos que receptáculo, lugar de acolhimento ou de hospedagem (hypodokhê), é a determinação mais persistente (não digamos essencial, por razões já evidentes) de khôra». (55)

Quanto a Édipo, que embora cego ainda nos olha, inclusive de esguelha, não deixa de ser relevante indagar se ele perfurou os olhos para não mais poder ver, tão somente, ou, de quebra, para nunca mais lacrimejar. Livrar-se do choro, enfim, não implicaria em abrir mão do recuo, ou apoio, de todo modo do voltar atrás que sustenta a disparatada fuga do fruir poético?

\section{...de eros}

É chegado o momento de nos deslocarmos para um outro templo, também este erigido em frangalhos. Erguido, no caso, a partir do reaproveitamento de dejetos acumulados há bem mais de dois milênios, onde mesmo brevemente entoaremos, breviários abertos, os devidos réquiens à memória dos armipotentes todos que em legião nos assolam, amém.

Tal templo é dedicado a Ulysses, nome grafado em seu pórtico, o êmulo de Odisseu esboçado pelas mãos pouco parcas de James Joyce, o desamusado escritor que o privou do portentoso suporte de alguma Ulysseia ou Ulyssíada. Isso contudo não impediu que Leopold Bloom, esse outro «herói multipaciente» (147), como poderia muito bem ter sido qualificado por Homero, pudesse experimentar, talvez como prêmio de consolação, uma sensaborosa emanação dos despojos da certeza e da cortesania lacrimejantes arrogadas desde o consórcio greco-feácio.

Então a mítica ilha de Esquéria, país dos feaces, cede lugar à Irlanda, Dublin em particular. No caso do canto em questão, ao «altivo promontório do nosso querido Howth», ${ }^{14}$ território que se projeta sobre o mar em direção a Gales e constitui quase uma ilha, já que ligado à cidade por uma estreita faixa de terra, ístmica. Os graves acontecimentos lá verificados ocorrem não mais em plena manhã, mas no crepúsculo da «Terra do sol poente» (592), onde o domínio dos deuses se encontra circunscrito aos limites de uma igreja, «singelo fano junto às ondas» no qual, «depois das tempestas deste mundo atribulado», os fiéis oravam em louvor a «Santa Maria, santa virgem entre as virgens» (561).

Nausícaa, neste cenário malproporcionado, aparece transmudada em Gerty MacDowell, moça de talhe «esguio e gracioso», «declarada linda por todos os que a conheciam (...), o botão de rosa de sua boca [constituindo] um legítimo arco de Cupido, helenicamente perfeito» (553). Assim, resume a voz narrativa, «ela estava tão adorável em sua doce pudicícia de menina que certamente a bela terra da Irlanda abençoada por Deus não lhe tinha par» (555). Ela, que «poderia chorar a valer e aliviar seus sentimentos reclusos mas não demais porque ela sabia chorar bem direitinho diante do espelho» (558), tem como companhia duas únicas raparigas, além de três crianças, naquele fim de tarde em que prosseguia anelando por seu

ideal de admirador (...), um homem viril com um rosto forte e tranquilo que não houvesse encontrado seu ideal, talvez com os cabelos levemente marcados por fios grisalhos, e que a compreenderia, tomá-la-ia em 
seus braços protetores, a apertaria com toda a força de sua profunda natureza passional para consolá-la com um beijo bem comprido. Seria o paraíso. (558-559)

A esse quadro idílico, atravessado por risos ou choros infantis e pelas dolentes antífonas e ladainhas cristãs, o senhor Bloom irá se incorporar. Pós-heróico, entra em cena após resgatar a bola chutada longe por uma das crianças e tentar lançá-la na direção da irmã mais velha, que a solicitara. Erra porém o alvo, caindo a pelota sob as saias de Gerty, puro acaso feliz que faz dela a nova responsável por recolocá-la em jogo. Ela tenta golpeá-la mas fracassa, sendo espezinhada pelas amigas.

Acertado o chute seguinte, o narrador, transitando do indireto livre, com o qual explicita a reação à zombaria, para o indireto, acentua, com base na perspectiva dela, o início do insinuante contato que irá entreter com Bloom:

Puro ciúme é claro que era só isso para chamar atenção por causa do cavalheiro do outro lado olhando. Ela sentiu o calorão, sempre um sinal de perigo (...), surgindo e inflamando suas bochechas. Até aquele momento haviam apenas trocado olhares dos mais casuais mas agora por sob a aba de seu novo chapéu ela arriscou lançar-lhe um olhar e o rosto que seus olhos encontraram no crepúsculo, lânguido e estranhamente convulso, pareceu-lhe o mais triste que jamais vira. (564-565)

A partir desse momento pós-herói e donzela se entregam ao exercício de um mútuo espreitar. No caso dela, um pouco mais discreto, mas nem por isso menos constativo. Olhando-o, vigia-lhe o olhar, e embevecida vai vendo ele se manter nela embebido. Enquanto isso principia a construir para si uma possível história dele, procurando decifrar o que lhe diziam os seus olhos, que em revide «penetravam-na queimando como se por perscrutá-la inteira, ler o mais fundo de sua alma» (566).

Uma dúvida que lhe atravessa o fantasiar diz respeito a proveniência de seu eleito de ocasião. Embora considerasse os olhos dele «magníficos (...), soberbamente expressivos», seria possível, questiona-se, «neles confiar? As pessoas eram tão esquisitas. Ela pôde ver de pronto por seus olhos negros e o pálido rosto intelectual que ele era estrangeiro» (566). A sombra de um estigma secular relativo a esse estranho estrangeiro, no caso temperado pelos eflúvios de um efusivo pavor sedutor, e que atravessa Ulysses de cabo a rabo, mais uma vez aqui se insinua, disfarçado nas palavras da jovem garbosa, que

não conseguia ver se ele tinha um nariz aquilino ou algo retroussé dali de onde estava sentada. Estava de luto fechado, isso ela podia ver, com a estória de uma dor perturbadora gravada em seu rosto. Ela teria dado mundo e fundos para conhecê-la. (567)

As divagações vão adiante, conspurcadas pela série de ironias que cintilam através do relato:

Aqui estava aquilo com que tanto sonhara. Era ele o que importava e havia alegria em seu rosto porque o desejava por ter instintivamente sentido que ele era diferente de todos. O coração da meninamoça corria todo para ele, seu marido ideal, porque ela soube de pronto que era ele. Se ele sofrera, mais vítima do pecado que pecador, ou mesmo, mesmo, se houvesse ele próprio pecado, sido um homem perverso, ela não se importava. Mesmo se ele fosse protestante ou metodista ela poderia convertê-lo se ele a amasse de fato. 
Havia chagas que requisitavam uma cura com bálsamos do coração. Ela uma mulher feminil diferente de outras meninas volúveis nada femininas que ele conhecera, (...) ela apenas ansiava por tudo conhecer, por tudo perdoar se pudesse fazê-lo se apaixonar por ela, fazê-lo esquecer a lembrança do passado. (567)

Ao mesmo tempo em que imagina ela o fascina. Em dado momento retira o chapéu, para ajeitar «seus maravilhosos cabelos fartos» de "mechas luxuriantes» (555), e pouco depois «quase podia ver a veloz onda de admiração provocada nos olhos dele que fazia vibrar cada um de seus nervos» (570). Chega a ter estado prestes a perder

o fôlego ao ver o olhar que lhe lançava. Ele a mirava como a serpente mira sua presa. Seus instintos femininos the diziam que ela havia acordado o demônio que nele residia e diante dessa ideia um flamejante escarlate varreu-lhe do pescoço à testa até tornar-se um rosa glorioso a linda cor de seu rosto. (570)

O jogo erotizado prossegue, em contraponto às pregarias e cânticos ecoando desde a igreja, a preia mais e mais conjungida ao predador, cujos olhos bebiam cada um de seus contornos, «literalmente em adoração diante daquele ícone» (572). A atmosfera aliciante leva a voz narrativa a diretamente interpelá-la: «Se um dia pôde haver uma admiração indisfarçada no apaixonado olhar de um homem lá estava ela exposta no rosto daquele homem. É por você, Gertrude MacDowell, e você sabe» (572).

Então fogos de artifícios explodem contra o ocaso do horizonte. Correndo na direção de onde são lançados companheiras e crianças deixam-na para trás, a ela que, permanecendo sobre a pedra na qual desde que chutara a bola estivera sentada todo o tempo, continua a navegar embalada pela maré montante de suas quimeras. Os dois agora enfim sós, os

olhos que nela estavam fixados faziam seus pulsos palpitar. Olhou para ele por um momento, devolvendo-lhe os olhares, e uma luz eclodiu sobre ela. Uma lívida e férvida paixão estava naquele rosto instalada, paixão silente como um túmulo, e fizera que ela se tornasse dele. (...) As mãos e o rosto dele se moviam e um tremor tomou o corpo dela. Ela se reclinou para trás inteira (...) e segurou o joelho com as mãos para não cair para trás olhando para cima e ninguém estava lá para ver somente ele e ela quando ela revelou inteiras daquele jeito suas graciosas pernas lindamente torneadas, sedosas e suaves, delicadamente redondas, e ela parecia poder ouvir o arquejar de seu coração, seu alento ríspido, porque sabia da paixão de homens como aquele, de sangue quente. (577)

que ademais acabava por finalmente borbulhar quando concluíam em jorro uma masturbação em curso, pois sua amiga Bertha Supple lhe contara alguns detalhes acerca desta prática.

Ela, porém, mantém-se aferrada às fantasias romanescas com que adoçava a cena, considerando que no seu caso «havia uma enorme diferença porque ela quase podia senti-lo puxar seu rosto para junto dele», e, depois, «o primeiro ligeiro toque cálido de seus belos lábios dele» (577). O orgasmo másculo coincide com o espocar de um rojão, «que saltou e bum com bom tom som de estrondo Oh! e todos gritaram Oh! Oh! em êxtases» (579).

Antes disso, contudo, o foco narrativo por um ínterim dela se afastara e dele se aproximara, privilegiando um átimo de seus olhares e pensares. A distinção torna possível vê-lo admirar o rosto dela sendo «tomado por um divino, um enfeitiçante rubor, de tanto se inclinar e ele podia ver as 
outras coisas dela também, calçolas de organdi, o tecido que afaga a pele» (578), isso até visto e vista se confundirem num visco meloso, uma vez que

ela deixou e viu que ele via e então subiu tão alto que saiu do campo de visão por um momento e todos os seus membros tremiam por se curvar tanto assim ele tinha plena visão bem alto além dos joelhos dela ninguém antes nem na balança ou vadeando e ela não sentia vergonha e nem ele sentia por olhar daquela maneira impudica daquele jeito porque ele não podia resistir à visão da formidável revelação semioferecida como aquelas bailarinas se comportando tão impudicas diante dos cavalheiros olhando e ele continuava olhando, olhando. (578)

Findo o júbilo dele, de retorno ao plano dela a onisciência contrasta o malogro de seu gozo, abstrato porém intemporal, e coletivo:

Ela estava disposta a gritar para ele, embargada, estender-lhe os esbeltos braços níveos por que viesse, para sentir-lhe os lábios pousados em seu cenho alvo o grito de amor de uma jovem, um gritinho estrangulado, arrancado dela, o grito que ressoa através dos séculos. (578-579)

A partir desse instante, num cenário que passa a ser em «tudo silente» (579), a narrativa se concentra nas impressões e reflexões dele que, só agora de fato nomeado, percebe que ela «lançou-lhe um olhar (...), um patético olharzinho de protesto pio, de tímida censura sob o qual ele corou como uma moça» (579). Então

Leopold Bloom (pois é ele) está calado, de cabeça baixa diante desses jovens olhos cândidos. Mas que monstro havia sido! De novo com isso! Uma alma pura imaculada o havia invocado e, desgraçado que era, como respondera? Um completo canalha! Logo ele! Mas havia um infinito sortimento de misericórdia naqueles olhos, também para ele uma palavra de perdão mesmo tendo ele errado, e pecado e se extraviado. As mocinhas têm de contar? Não, mil vezes não. Era o segredinho deles, só deles, sós no crepúsculo ocultante. (579)

A ponto de sair de cena a jovem «teve uma ideia, um dos pequenos ardis do amor» (579): retira o chumaço de algodão perfumado que trazia no bolso e com ele na mão acena, despedindo-se e ao mesmo tempo deixando-lhe como prenda o aroma de seu corpo exaltado. Só depois ele logrará senti-lo, mas nesse momento ele já estará atormentado pelo fantasma de Molly, a Penélope que o trai, e ele o sabe.

Gerty enfim se levanta, dirige a ele «um meio sorriso vago, um doce sorriso de perdão, um sorriso que beirava as lágrimas, e então se separaram» (580). Ela se retira caminhando "com certa dignidade tranquila característica sua mas com cuidado e muito lentamente porque» ela era, agora ele irá constatar, a exemplo da Eugênia de Brás Cubas, donzela dotada de uns «olhos tão lúcidos, uma boca tão fresca, uma compostura tão senhoril», ${ }^{15}$ ela também era "coxa! Oh!» (580).

A reação é contudo fria, quase indiferente não fosse o cinismo acachapante. Calmo, ele

ficou olhando enquanto ela saía coxeando. Coitadinha! Por isso ela ficou largada e as outras saíram correndo. Achei que tinha alguma coisa errada pelo jeito dela. A bela desprezada. Um defeito é dez vezes pior 
em uma mulher. Mas ficam educadas. Que bom que eu não sabia quando ela estava se exibindo. Diabinha assanhada mesmo assim. Não ia me importar. (580)

O próximo passo é inculpá-la. Ao fazê-lo passo a passo dissipa a imaginação de que parte para assim estender mais livremente a responsabilidade às mulheres todas, tidas como culpadas pelos desvarios masculinos. Porque, afinal,

perto das regras, imagino, (...) elas mesmas é que querem. Uma necessidade da natureza delas. Catadupas delas toda noite jorrando dos escritórios. Reservar as melhores. Não quer elas jogam na sua cara. Pegar vivas, larará. (...) Elas também ficam excitadas quando estão. Estou toda limpinha vem me sujar. E elas gostam de uma vestir a outra pro sacrifício. (...) Sempre atrás de algum sujeito quando estão. Nunca esquecem um compromisso. Na tocaia provavelmente. Elas acreditam no acaso porque elas também. (...) São uns diabos quando está pra vir. Uma aparência sombria de demônio mesmo. (580-581-582)

$\mathrm{O}$ arrependimento, se existente, além de leve é também breve. Enquanto recompõe a camisa manchada pela porra dissipada o senhor Bloom racionaliza ainda: «Ah Senhor, aquela diabinha coxa. Começando a ficar frio e melado. Efeito colateral desagradável. Ainda assim você tem que se livrar disso de algum jeito. Elas não se importam. Lisonjeadas quem sabe» (583). Nesse universo adulto e perverso, no qual predomina a dissimulação, a anestesia torna-se norma: «E agora? Triste de ela ser coxa mas você tem que estar alerta pra não sentir pena demais. Elas se aproveitam» (593). O que não impede de ele chegar a supor ter ela alcançado um prazer correlato a seu próprio gozo, senão por este suscitado: «Eu diria que ela sentiu que eu. Quando você se sente assim às vezes acaba encontrando aquilo que sente. Gostou de mim será? (...) Viu alguma coisa em mim. Fico imaginando o quê» (582-583).

Pergunta capciosa, já que quem a formula tem certeza do que ela não viu. Ou melhor, aquilo que, dele, não deixou que ela pudesse ver: um efusivo detalhe de sua anatomia, um estigma que aciona o conjunto de preconceitos que o cercam, e que como assinalado atravessam todo Ulysses. Sua confissão, de que não havia deixado «ela me ver de perfil. Ainda assim, nunca se sabe» (583), pode ser considerada enquanto síntese de algumas formulações de Marie-José Mondzain, para quem o judeu, «que pode ser reconhecid[o] por seu perfil», «é como seu nariz: uma imagem da sombra; sombra por essência, ele é o rosto da morte sem ressurreição». ${ }^{16}$

Mondzain observa que o perfil judaico, considerado deste viés, a princípio inverte «o discurso sobre o perfil grego» (275), cuja harmonia e equilíbrio faz com que ele, dado o contraste, venha a ser «exilado do logos e da beleza». Com a progressiva institucionalização do cristianismo, prossegue ela, as feições hebraicas estereotipadas acabam por se encontrar privadas da possibilidade «de qualquer redenção» (276). A visão de perfil, segundo a qual Cristo nunca deve ser figurado, torna-se com isso a imagem judaica per se, uma funesta exclusividade. Assim, na medida em que «o rosto crístico tem um propósito soteriológico, pela segunda vez o judeu é excluído» (278, modificada). Daí ser normal, e recorrente, que ele apareça como um corpo estranho, «um corpo que perdeu seus direitos ao nome de homem e ao olhar de Deus» (280).

Embora sabedor da intolerância de que é objeto, Bloom ousa desafiar dois preceitos a um só tempo. Pois ele não apenas olha a moça de frente, e esconde de seu rosto o que não deve ser percebido, resgatando com isso ao menos um naco de seu periclitante nivelamento frente aos demais, 
mas ainda se masturba, ao modo de um voyeur sobre-exaltado, diante de uma ninfeta nabokoviana com quem pouco interage. Sua excitação é isso mesmo: um encontro forjado, manco ou frustrado, com alguém que é, de fato, prejudicado por uma deformação física adventícia, e por isso posto à parte, descartado senão segregado.

Como antes de que tudo ocorresse expusera o narrador, com a habitual sutileza, Gerty personaliza uma donzela romântica, bovaryana, apaixonada pela palavra, e que a seu modo tentava ocultar ou sublimar seu estigma. Ela também padecia da

beleza da poesia, tão triste em sua delicadeza transitória, [que] nublara seus olhos com lágrimas silentes porque os anos já se lhe escapavam, um a um, e não fosse por aquele pequeno contratempo ela sabia que não precisava temer quaisquer competidoras e aquilo tinha sido um acidente descendo a colina Dalkey e ela sempre tentava esconder. Mas havia de acabar ela sentia. Se ela visse aquela mágica atração em seu olhar não haveria o que pudesse detê-la. Ri-se o amor dos cadeados. Ela faria o grande sacrifício. Todos seus esforços seriam para compartilhar dos pensamentos dele. Mais preciosa do que tudo neste mundo ela seria para ele e douraria seus dias de felicidade. Havia a questão de maior monta e ela morria de vontade de saber se ele era casado ou um viúvo que perdera a esposa ou alguma tragédia como o nobre com nome estrangeiro vindo da terra da canção que teve de levá-la a um hospício, cruel somente por ser bom. (575-576)

Esvaziada de qualquer dádiva de amor, a satisfação do desejo é literalmente produto de mão única. Configura um típico prazer solo cultivado em uma civilização que não cansa do mesmo repetir, como a ladainha vinda da missa afinal encerrada, no decorrer da qual fora possível «ouvir todo mundo junto. Orai por nós. E orai por nós», o que leva Leopold Bloom a concluir ser uma boa «ideia a repetição», cuja sabedoria de imediato aplica, colocando-a a serviço de suas ambições: «Mesma coisa com os anúncios. Comprai de nós. E comprai de nós» (594).

Nesse mundo mercantilizado, estar ao lado dos carrascos ou dos perseguidos periga tornar-se mera contingência, uma vez que tanto os culpados como as vítimas sempre são os outros. Pouco importa que no episódio imediatamente anterior ao seu encontro com Gerty MacDowell ele tenha se colocado como membro de uma raça «que é odiada e perseguida. Ainda hoje. Agora mesmo. Neste mesmo instante» (533), antes de ser descrito por um conhecido como um «lobo em pele de cordeiro», e em seguida identificado com ninguém menos que o Judeu Errante. A alusão direta, «Ahas Verus é o meu nome pra ele. Amaldiçoado por Deus» (541), traz consigo um enxame de referências nada abonadoras que atravessam, de há séculos, quando menos a cultura ocidental. Ele, justo ele que sabe que precisa «voltar. Os assassinos sempre», não se exime de indagar, entretanto: «Eu vou?» (600).

Desde sua pedra a sereia lhe enviara o perfume que guardava junto a seu seio, como recordação. Bloom, por sua vez, antes de partir resolve, na areia da praia, deixar escrita «uma mensagem pra ela». «Pode ser que fique». Sobrevém uma nova dúvida: «O quê?» Com uma vareta traça: «EU». Supõe que alguém pisará sobre o escrito, que as ondas acabarão por apagá-lo. Então se inclina sobre uma pequena poça, vê nela seu rosto, defronte. Num repente assopra a água e a face se efaça, movente. Ele porém prossegue sua faina. E rabisca: «SOU. UM.» (600), assim mesmo, em caixa alta.

Para por aí e exclama: «Acabou o espaço. Largue mão». Apaga as letras com sua «bota lenta», raspando a areia, coisa essa a "mais inútil», onde não "cresce nada», onde tudo «fenece». Por fim se arroga: «Feito meio de propósito» (600). E se despede de sua presa, até jamais, não sem antes 
sublinhar os benefícios que ela lhe trouxera: «Acaso. A gente nunca mais vai se encontrar. Mas foi lindo. Adeus, querida. Obrigado. Fez eu me sentir tão jovem» (6oo).

Também o senhor Bloom, pós-heróico greco-feácio-egípcio-judaico-cristão novulysses encontra-se ex-crito. É ainda um singelo sujeito em falta de si, ausente de sua própria presença, e, por conseguinte, pouco concernido quanto à presença de outrem. Nada surpreendente, dado que não existe e jamais existiu algo como um sujeito íntegro, assim sem mais nem menos, sem ter o que pôr ou tirar. Decerto que sujeitos de e sujeitos a ainda há, e já passou da hora de quebrar sua pretensa totalidade totalitária, de estilhaçar as imagens únicas que projetam ou sobre eles são projetadas, e que de qualquer maneira os perseguem como a sombra de cada um deles inseparável, caso ainda haja alguma luz. Trocá-los e tocá-los por imagens que os fragmentem. Imagens das linguagens todas, sem o consórcio das quais os enigmas definham até o esvaecimento. São elas, linguagens, os corpos privilegiados, porquanto desprovidos de essência, em relação aos quais nós, simples formas de vida, em nossa mortalidade somos não objetos ou complementos, mas ledores. E fruidores de mais a mais em dúvida e em dívida, a dispor. Para o bem ou para o mal, as linguagens afetam os corpos que percebem.

\section{Notas}

1 Todas as referências à Odisseia remetem à edição bilíngue, com tradução de Trajano Vieira, publicada pela editora 34 (no caso, a 2a edição, de 2012). Os fragmentos citados provêm da página 13. Como as posteriores inserções emprestadas da epopeia foram retiradas desta mesma edição, doravante as indicações serão fornecidas no corpo do texto, entre parênteses.

2 O conceito de «ex-critura» remete a Georges Bataille, tendo sido contemplado com instigantes reflexões propostas por Jean-Luc Nancy. Para este «Bataille siempre ha representado la impotencia de acabar, el exceso, tendido hasta romper la escritura, de lo que hace la escritura: es decir, de lo que simultáneamente la inscribe y la excribe» (en «Lo excrito», Nancy 2002:39-46).

3 Relatos provenientes de outras personagens, como Proteu, por exemplo, ressaltam de igual modo ocorrências de choro, reiterando-as. Ao referir a Menelau sua visita a Odisseu, aquele afirma que o encontrara «na morada de Calipso, ninfa, chorando» (127).

4 Numa cena em tudo especular com relação a essa experimentada pelo herói, Telêmaco, quando ouve a peroração de Menelau a propósito das adversidades que atribulavam seu pai, «quis chorar por Odisseu: as gotas decaem dos cílios empoçando o chão em volta, tão logo ouviu seu nome. Leva o manto rubro aos olhos. Menelau percebe a situação» (101).

5 Italo Calvino (17-24).
6 Jean-Luc Nancy, en «Corpo Nudo» (2015:17).

7 Jean-Luc Nancy, em «Sobre a destruição» (2014a:38).

8 Walter Benjamin, «Sobre a pintura ou Signo e mancha» (2011:83). Como as posteriores inserções foram retiradas desta mesma edição, doravante as indicações serão fornecidas no corpo do texto, entre parênteses.

9 Por exemplo em ¿Un sujeto? (2014b).

10 Conforme Peter Sloterdijk, «Sigmund Freud e Derrida», Derrida, un egipcio (2007:26-33).

11 Aristóteles, Arte retórica e arte poética, (1964:294). Como as posteriores inserções foram retiradas desta mesma edição, doravante as indicações serão fornecidas no corpo do texto, entre parênteses.

12 Para ficar no Canto IV: Menelau revela a Telêmaco chorar pelos "heróis tombados na planície troica», entre os quais nomeia Odisseu, cujo destino «tortura-[o] sobremaneira» (101). Em resposta, como consta na nota 3 deste ensaio, Telêmaco se desfaz em prantos. Pouco depois, quando Helena reconhece o moço, por semelhança, como filho do herói ausente, o elogio dirigido por Menelau ao companheiro de armas produz uma choradeira coletiva, perdurante até aquela outra vez intervir, cena essa a seguir discutida no corpo do texto.

13 Jacques Derrida (10) (itálicos do original). Como as posteriores inserções foram retiradas desta mesma edição, 
doravante as indicações serão fornecidas no corpo do texto, entre parênteses.

14 James Joyce (550). Como as posteriores inserções foram retiradas desta mesma edição, doravante as indicações serão fornecidas no corpo do texto, entre parênteses.
15 Machado de Assis (77).

16 Marie-José Mondzain (270 e 271 respectivamente). Como as posteriores inserções foram retiradas desta mesma edição, doravante as indicações serão fornecidas no corpo do texto, entre parênteses.

\section{Referências bibliográficas}

Aristóteles. Aristóteles, Arte retórica e arte poética. SP: Difel, 1964. Tradução de Antônio Pinto de Carvalho.

Benjamin, W. (2011). Escritos sobre mito e linguagem. SP: Duas cidades/34. Tradução de Susana Kampf Lages e Ernani Chaves.

Calvino, I. (1993). Por que ler os clássicos, SP: Cia das Letras. Tradução de Nilson Moulin.

Derrida, J. (1995). Khôra. Campinas: Papirus. Tradução de Nícia Adan Bonatti,

Homero. Odisseia. (Edição bilíngue). 2da edição. SP: 34, 2012. Tradução de Trajano Vieira.

Joyce, J. (2012). Ulysses. SP: Penguin/Cia das Letras. Tradução de Caetano W. Galindo.

Machado de Assis, J. M. (1968). Memórias póstumas de Brás Cubas. 5ta ed. SP: Cultrix.

Mondzain, M.-J. (2013). Imagem, ícone, economia (As fontes bizantinas do imaginário contemporâneo). RJ: Contraponto/MAR. Tradução de Vera Ribeiro.

Nancy, J.-L. (2002). Un pensamiento finito. Barcelona: Anthropos. Tradução de Juan Carlos M. Romo. (2014a). Arquivida (Do sensciente e do sentido). SP: Iluminuras. Tradução de Marcela Vieira e Maria P. G. Ribeiro.

- (2014b). ¿Un sujeto? Buenos Aires: La Cebra. Tradução de L. Felipe Alarcón.

(2015) Corpo, fora. RJ: Sete letras. Tradução e organização de Márcia Sá Cavalcanti Schuback.

Sloterdijk, P. (2007). Derrida, un egipcio (El problema de la pirámide judía). Buenos Aires: Amorrortu.

Tradução de Horacio Pons. 